\title{
Storying Ubuntu as a rainbow nation
}

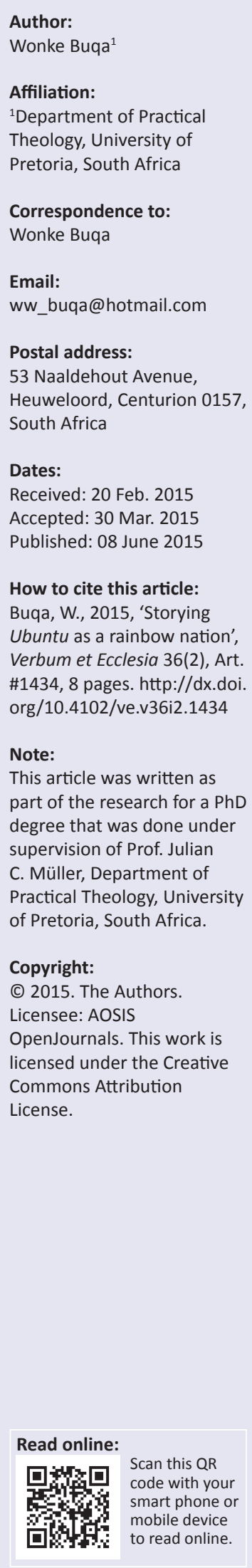

South Africa is often referred to as the 'Rainbow Nation'. This term was coined by Desmond Tutu during the advent of democracy in the country. Tutu stated: 'They tried to make us one colour: purple. We say we are the rainbow people! We are the new people of the new South Africa!' This article seeks to answer the question as to whether the Rainbow Nation is a true reflection of Ubuntu in South Africa or whether it is just idealism.

\section{Introduction}

An African world view that underpins much of African values and social thinking is Ubuntu (Broodryk 2005). Jolley (2011:59) and Bernhard (2011:43) state that Ubuntu became one of the key concepts of the new democratic South Africa which inspired people of different races to embrace one another after apartheid. This article attempts to respond to this claim about Ubuntu through a literature review and a narrative inquiry amongst people living in a multi-racial urban township known as Olievenhoutsbosch.

In this article, I shall listen and explore these people's lived experiences concerning the 'Rainbow Nation' and Ubuntu in the 21st century. This will be done by means of narrative research amongst South Africans of varying races, ethno-cultural groups and socio-economic classes.

In this regard, practical theology is a field of study that prides itself in taking human experiences seriously. I shall focus on embodied stories emanating from the local and concrete context of Olievenhoutsbosch. McAllister (2009:2) expresses the view that Ubuntu has become a key notion amongst elite circles in South Africa, particularly in the context of the demise of apartheid and the process of nation-building that followed. This narrative of McAllister finds its point of departure in the celebration of the abolishment of legal racism in South Africa in 1994 and in the development of the new constitution, which is considered to be one of the most progressive of its kind in the world. People have rights, and there are institutions that are designed to protect and uphold those rights.

The dominant belief was that, through a commitment to the ideals of national reconciliation and the Rainbow Nation, ${ }^{1}$ all of society's historical problems would be overcome. National reconciliation and the idea of the Rainbow Nation were generally regarded as the main pillars of social cohesion and integration (Mathebe 2002:139).

However, the situation in South Africa during the past 20 years of democracy (1994-2014) opens up challenging narratives about the meaning of Ubuntu and the Rainbow Nation. For some, the Rainbow Nation became an empty term in the light of all the promises of the government whilst, as yet, they do not have water to drink or a place to sleep. They also do not receive the practical aid and help that they have been expecting. Hence Biko (2013:232) argues that this newly established consumer-centric ideology clashed with traditional African values such as Ubuntu, impinged on the ability of citizens to continue to lead faith-based, family-centred lifestyles and diminished the community-orientated recreational habits of the past.

The relevance of my article lies in its emphasis on a local context with reference to concrete and embodied, lived experiences of the relevant people. It therefore finds its point of departure in practical theology as a way of life. The article contributes towards the discipline of practical theology in the sense that the focus is on in-context experiences from which theory is developed which, in turn, can inform similar and different contexts from which angles alternative and new theoretical narratives can grow.

1.Rainbow Nation was described by Tutu to encapsulate the unity of multi-culturalism and diversity of South African people. This term was furthered by Nelson Mandela as the first democratically elected President of South Africa in 1994. 


\section{The context: Olievenhoutsbosch}

Olievenhoutsbosch is the first urban township that I came across in South Africa that consists of inhabitants from almost all of the races, classes, socio-economic statutes and ethnic groupings living in a township area. It is situated along the Centurion-West suburb of Pretoria on the way to Midrand. It consists of Reconstruction Development Programme (RDP) housing, informal settlements, town houses and normal houses. Olievenhoutsbosch, also known as Olieven, it is a vibrant community with its own challenges like any township in South Africa. These include socio-economic crises, crime, violence, service-delivery protests and informal settlements. In this context, I shall embark on a journey of conversations with two co-researchers from Olieven, as a case study. Muller (1999:1) describes that life is a journey. If you are alive, you have made a start, and you are on the journey.

\section{Olieven stories}

Clandinin and Connelly (2000:17) attest that life as we come to it and as it comes to us is filled with narrative fragments, enacted in storied moments of time and space, reflected upon and understood in terms of narrative unities and discontinuities. Some people in Olieven perceived the Rainbow Nation as an empty term if they do not have water to drink or a place to sleep or if they do not receive the practical aid that they have been promised by the government. Hence Meskell (2012:46) argues that some South Africans he interviewed expressed themselves as 'tired' of Rainbow narratives. They felt that changes in social perceptions were being forced rather than developed.

In narrative pastoral work, story is not seen only as a means of releasing information but also as a way to come to yourself (Muller 1999:2). This is why people are led to tell and retell their stories in such a way that reinterpretation and reconstruction can eventually happen. It is significant to note that the focus in narrative research is more on people's experiences rather than the mere literature. Van der Westhuizen (2008) explains it as follows:

In many theses, literature studies precede the research process. In our positioning literature follows the stories listened to and described. The reason for this is that within our approach the moment of praxis is the starting point. The narrative of the research process leads us to the literature or text. In practical theological terms, the context leads us to the text and back to the context. (p. 207)

In Van der Westhuizen's view, scholars in practical theology espouse the epistemology that people are the living texts although it is also vitally important to attest to the literature.

\section{Interviews with Ms Grace Ngidi}

On Friday, 15 August 2014, I visited Ms Grace Ngidi, a Zulu lady who stays in Olievenhoutsbosch Township at extension four. Ms Ngidi gave me permission to name her in the article. Grace is one of the co-researchers in my $\mathrm{PhD}$ research with the title: 'Ubuntu values in an emerging multi-racial community: A narrative reflection'. Grace is 41 years of age and a widow with one child, a daughter named Nomfundo. Grace has a Bachelor of Arts degree in Communication Science and works in the position of a manager at the Auditor General of South Africa. She is also a Deputy GeneralSecretary of the Uniting Presbyterian Women's Fellowship in Southern Africa and a staunch African National Congress (ANC) member. She was born in KwaZulu-Natal and grew up in Soweto in Gauteng. The opening question in the interview with Grace was: 'When people talk about the term "Rainbow Nation" in South Africa, what do you understand about this term, and what does it mean to you as a resident of this community of Olieven?':

Mrs. Ngidi: ${ }^{2}$ The term 'Rainbow Nation' represents our nationality, our identity and that our differences are immaterial; we are united in our diversity. It represents a young nation that is still trying to find itself. South Africans are different from Americans though, in terms of national pride. Americans are proud and patriotic about their identity. Wherever they are competing or when there is an issue of national importance, you will find them screaming at the top of their voices: 'USA! USA! - USA' To us South Africans, the term 'Rainbow Nation' means our different cultures, races, ethnic groups and genders imply inclusivity. In our Constitutional Preamble, it says South Africa belongs to all who live in it and that we are united in our diversity. It is part of the meaning of the Rainbow Nation that we are one nation regardless of our various backgrounds and cultures. We are talking about blacks, Indians, mixed race, whites, physically disabled people; it is part of fostering unity and patriotism, - developed by Nelson Mandela. It forms part of our national psyche.

Wonke: ${ }^{3}$ Now, in view of what you said just now, could you please share with me what happened during the protest that blocked the R55 road at Olieven in demand of service delivery on 15 April 2014?

Mrs Ngidi: When the people of Olieven were protesting against the failure of service delivery, they closed R55 road, burnt tires, and the police came to monitor the protest. The police wanted to stop three white men who were driving to Olieven, and they said the place is dangerous. The white men told them that they are residents of Olieven, and there is nowhere else they can go. Eventually, the police allowed them to drive through, and they were known by the residents while the police were astonished to see white men staying in a township. I think, Mfundisi [Reverend], it's the kind of the Rainbow Nation that Mandela envisioned for South Africa.

Wonke: This is a positive story, but what do you perceive as impediments to the Rainbow Nation?

Mrs. Ngidi: Trust is the number one disabler and the doctrine of inequality and apartheid that was preached to the whites about blacks for decades and how blacks perceived whites as enemies as the results of injustices practised to blacks by whites, e.g. superiority was preached to whites from a young age, and they grew up knowing that as the ultimate truth. In their view, blacks are not intellectual like white people. That on its own creates a barrier and classes amongst people, feeding into suspicions as a result of teachings that were wrong. Segregation contributed

2.Ms Grace Ngidi, 41-year old female, with a B.A., working as manager in the Auditor-general's office.

3.Reverand Wonke Buqa, author of the article. He is a 37 -year old male, PhD student at UP, working as a seconded minister in the South African Air Force. 
to this, in the past even public amenities were categorised into Europeans only or whites only and Non-Europeans as if being European was the benchmark. Blacks did not have identity then as they were called non-whites.

These are the things that divided the nation, we were like none entities in a land of our birth, segregation of education amongst racial groups resulted into blacks being fed a poor quality of education which ensured that thinkers and scientists do not come out of the black community. These on its own are impacting on progress and have made black graduates to be unemployable as they lack the necessary foundation and to be enablers of development like mathematics and science. This was done to make sure that generations do not bridge the class divide. Our history of segregation and Bantu education caused us to be hesitant to reconcile. There is a lot of damage that was done to a black person.

\section{Interview with Ms Mellnie Beukes}

On Tuesday, 19 August 2014, I visited Olievenhoutsbosch extension 36, an RDP area also known as ABSA. The place is called ABSA since it was an RDP project developed by ABSA bank in co-operation with the government. The purpose of the visit was to meet my mixed race ${ }^{4}$ co-researcher, Ms Mellnie Beukes, ${ }^{5}$ who has granted me consent to use her name in the article. Mellnie is a single lady, 23 years of age, staying with her sister. Their mother works in Germiston and only comes home over the weekends. When Mellnie completed matric, she went to study drama part-time. She is assisting in a drama series at the South African Broadcasting Corporation (SABC) and her wish is to be full-time employed in the art and recreation industry:

Wonke: Why did you move from the mixed race community to Olieven?

Mellnie: It was a new development; we were tired of being in Eersterus, and we wanted to move out from there. We wanted a new start, getting out of the mixed race community, we wanted a new environment. In Eersterus, people were judging a lot, we wanted a community that respect, and it is here that we experienced Ubuntu.

Wonke: What is the value of Ubuntu that you experience in this community?

Mellnie: We respect each other, we help one another, and we love one another. This is not a big community like Eersterus, but the community is developing. We also have white people in extension 4 . The only challenge we have is the drugs brought by foreigners, and unemployment. The community got tired one day and burnt down the shop which was owned by a Nigerian who was selling drugs. Nevertheless, we enjoy being here, we drink together, we sit together, we have black friends, and we do things together. There is Ubuntu here that we had never experienced in Eersterus.

Wonke: When people talk about the Rainbow Nation in South Africa, what do you understand about this term, and what does it mean to you being in the community of Olieven?

Mellnie: Rainbow Nation means different cultures interacting together; you can marry any person from any race or ethnic group. There is no limitation in the Rainbow Nation; you can 4.Designation preferred by co-researcher.

5.Ms Mellnie Beukes, 23-year old female, with matric, working part-time at the SABC. stay with whoever you want. You have a freedom of movement. I love this Rainbow Nation.

Wonke: What do you not like about the Rainbow Nation?

Mellnie: Some South Africans are so stuck in apartheid; other people are accusing each other on account of racial discrimination. Some people are so programmed in the past instead of moving on. We must change the government together if we want success. Other people continue to differentiate between blacks and whites. For me, I believe the Rainbow Nation encourages transformation and change.

\section{Reflecting upon interviews of the co-researchers}

Ms Ngidi seemed to be well informed about the Rainbow Nation. She relates it to inclusivity of all South Africans, quoting the Constitutional Preamble. She can compare the 'Rainbow Nation' with the national pride of Americans as the USA is their pride, their identity. It is significant to note the idealism of the Rainbow Nation as the police thought that it was dangerous for white men to enter Olieven during the protest, but the black residents allowed the white men to pass through as they knew them. This reveals how badly apartheid segregated people. Nevertheless, Shutte (2001:188) states that South Africa is a model, or it can be as it moves from apartheid towards Ubuntu.

Having listened to the story of Mellnie, I also observed that she mentioned the term Ubuntu before I could use it in our conversation. This gave me an indication that she knows Ubuntu. She said that her parents decided to leave Eersterus, looking for a community where they could experience respect. Eventually, they found Olieven with values of Ubuntu.

Mellnie also reflected critically on a story of another dimension of Ubuntu when the community burnt down the shop which was owned by a Nigerian who was selling drugs. It is interesting that she uses Ubuntu in this regard as challenging the bad work of an individual in the community. Lundin and Nelson (2010) explain the nature of Ubuntu as follows:

When someone in the village is acting in a way that threatens the harmony and unity of the community, the elders take action. Ubuntu is a compassionate philosophy, but it is not soft. When the group is threatened by an individual's behaviour, that individual must be challenged. (pp. 37-38)

\section{Integration of interviews and literature reflection}

I conducted the qualitative interviews on Ubuntu and the Rainbow Nation in order to integrate the stories of co-researchers coming from different ethno-cultural backgrounds, ages, levels of experience and education as well as co-researchers residing in various extensions within Olieven community. In support of this, Rubin and Rubin (1995:3) state that qualitative research listens to people as they describe how they understand the worlds in which they live and work. It is interested in the perspectives of the coresearchers and their experiences.

Mellnie mentioned that Olieven Township is a developing community as it also has white people. She is taking 
cognisance of the white residents in her community since it was not a common phenomenon during apartheid. She views this integration of different races in a township as part of Ubuntu. Hence Mbigi (1997:2) postulates that Ubuntu expresses values and behaviour that are not narrowly racial or purely sectional when practised in a given society.

Mellnie explained further by saying that, in Olieven, they drink, sit, chat and do things together. She also understands that, in the Rainbow Nation, one can marry anyone regardless of race or ethnic group. However, she is concerned that some people are accusing each other on account of racial discrimination. In this regard, Msengana (2006:8) critically evaluates the current situation, claiming that ordinary citizens do not yet have any clear sense of national identity and tend to maintain an ethnic mind-set. Race and colour seem to remain the principal axes of consciousness, and some people think of themselves as either black or white people.

Ms Ngidi views one of the concerns of the Rainbow Nation as mistrust between black and white people, due to the doctrine of inequality that was perpetuated by the apartheid system. The gurus of Ubuntu such as Mbigi (1997), Shutte (2001), Tutu (2005) and Broodryk (2005) vehemently advocate for the philosophy of Ubuntu as part of a tradition that coax peace and unity in South Africa. Jolley (2011), however, argues that most South Africans were not afforded an opportunity to decide for themselves. Instead, they were coaxed into applying the tradition of Ubuntu.

\section{Ubuntu and Rainbow Nation}

Ubuntu is the essence of being human. Tutu (2011:21) says that, in isiXhosa, people say, 'Umntu ngumtu ngabantu'. This expression is very difficult to render in English, but I could translate it by saying that 'a person is a person through other persons'. Tutu (2011) continues to say that Ubuntu speaks of spiritual attributes such as generosity, hospitality, compassion, caring and sharing, which means that one could be affluent in material possessions but still be without Ubuntu. Tutu adopted the concept of Ubuntu in an attempt to bridge the gap of ingrained racial barriers in South Africa in order to bring harmony and healing.

Given this understanding of Ubuntu, it is an Africanembedded philosophical approach to human life. It would be misleading to speak of Ubuntu and then to mistreat others on the basis of their race, culture, creed, gender or status. Ubuntu demands respect for human dignity regardless of any outward appearances.

In isiXhosa, a person who acts selfishly towards others would be called akanabuntu lamntu [that person is heartless] whilst a person who is kind and respectful towards others would be called unobuntu lamntu [that person is people-centric].

Unfortunately, in the current government of South Africa, Ubuntu is being challenged by the consumer-centric attitudes which Dr Vellem calls theology of the stomach. ${ }^{6}$ Hlumelo Biko (2013:27) claims that this emerging consumerism coincided with the advent of democracy in 1994, ushering in a new era where people began to robustly embrace consumer products that they had been forced to live without for most of their lives. This kind of consumerism is in direct conflict with Ubuntu. Hence Biko (2013) postulates the following:

Part of what South Africa currently struggles with is the search for an active repellent of the attack on this most sacred value of Ubuntu. The solution to this problem is to be found in actively embracing the struggle against poverty and inequality as the national struggle for economic liberation of this generation. It is only through the active engagement of all South Africa's citizens in this war on poverty that we can rediscover the spirit of Ubuntu. South Africans have to embrace people-centricity as a guiding principle for a national battle for shared prosperity. Unfortunately the spirit of Ubuntu has not facilitated an economic settlement between whitedominated corporate South Africa and the black-dominated government. (p. 27)

Biko affirms the sentiments expressed by Tutu, namely that Ubuntu speaks to the fact that one cannot exist in human isolation. Nevertheless, he also highlights the poignant problem of materialism in the advent of democracy. This materialism has brought ukungabinabuntu ebantwini [a lack of people's humanness amongst each other].

The critique of Ubuntu by Biko challenges the serenity of the Rainbow Nation. Xenophobia, racism, gang activities, corruption, inequality, nepotism and poverty are not part of Ubuntu and are not presenting the ideal of the Rainbow Nation of Madiba. Biko (2013; Johnson 2009:3) quotes Mandela's words regarding this ideal:

We enter into a covenant that we shall build the society in which all South Africans, both black and white, will be able to walk tall, without any fear in their hearts, assured of their inalienable right to human dignity - a rainbow nation at peace with itself and the world. Our single most important challenge is therefore to help establish a social order in which the freedom of the individual will truly mean the freedom of the individual. We must construct that people-centred society of freedom in such a manner that it guarantees the political liberties and the human rights of all our citizens. (p. 232)

This was the opening statement of the first democratically elected President of South Africa, Nelson Mandela, on 10 May 1994 in his inaugural presidential address at the Union Buildings in Pretoria, South Africa. Mandela's statement drew the attention of the whole world onto South Africa as many people were expecting violent revenge on the part of black South Africans against the white minority oppressors. Instead, South Africa, throughout its democracy, became a multi-racial, multi-cultural Rainbow Nation. Ubuntu was a central principle to recover and reconstruct the South African society from apartheid and to build the new Rainbow Nation. TPCSA ministers whilst he was a General Secretary of the Church. He express the the plight of religious leaders that embark on enriching themselves and the lack of prophetic ministry especially in critique of the government in advent of democracy. He has been a professor at the University of Pretoria since 2015. 
Was it not for this human embracement, bloody racial violence might indeed have occurred in South Africa.

Building South Africa upon the domestic vision of the Rainbow Nation, the African Renaissance demanded a cultural re-engagement with the rest of the continent with South Africa at the helm (Meskell 2012:45). Ubuntu is completely contrary to inhuman behaviour; it is the art of being human. It was, amongst others, due to the strong presence of the notion of Ubuntu in the hearts and minds of the people of South Africa that the country did not experience a violent revolution.

According to Broodryk (2007:48), the philosophy of Ubuntu embraces peace and negotiation because Ubuntu favours group solidarity. It seems to be necessary to deconstruct the idealism of Nelson Mandela and Desmond Tutu on the concept of the Rainbow Nation and Ubuntu in South Africa. One can ask whether the concept of Rainbow Nation is merely an idealistic symbol of liberation in South Africa and whether it is the most appropriate concept in present SouthAfrican public life.

This remains a critical issue in South Africa as politicians and religious leaders forged South African society together through these ideals. The uninterrupted transition and the forging of nationhood through these concepts of Ubuntu and the Rainbow Nation created the perception of South Africa's exceptionalism. However, some South Africans believe that, in the 20 years of democracy, the government has failed to equalise material and social relationships in society. Hence Jason Hickel (2014) argues that, whilst much has improved in the country over the past two decades, everyday life for most South Africans remains a struggle.

This struggle contribute to the claim that most South Africans do not perceive Ubuntu as smooth or as pervasive as the Rainbow Nation would like to acknowledge. Working with the narrative research of social constructionism leads me to consider the ways in which people's social and interpersonal realities have been constructed through interaction with other human beings and human institutions and to focus on the influence of social realities on the meaning of people's lives (Freedman \& Combs 1996:1). The concept of the Rainbow Nation should be tested through people's stories of what it means to them to be South African.

\section{Ubuntu in post-apartheid}

It is generally argued that the first contact between black and white people occurred under conditions of colonialism conflict, discrimination and competition, amongst others, which manifested themselves under segregation and apartheid (Mathebe 2002:138-139). This started with the arrival of Europeans in the 15th century. The question is whether Ubuntu or a lack of Ubuntu made any contribution to colonial conquest.

Swanson (2007) argues that Africans have used the collectivistic perspective of Ubuntu (I am because we are) to combat colonisation. The question is how the concept of Ubuntu has been applied, if so, in the context of multiracial and multi-cultural communities in a democratic South Africa.

As one might expect, there has been a great deal of resistance and fear of the unknown during the period of transformation. Transition is not always easy. However, it is the task of South-African people in their diversity to apply Ubuntu in a social way of living together for a better future.

South Africa is now called the Rainbow Nation because this means unity within multi-culturalism and the coming together of people of many different races. Msengana (2006:4) and Mbigi (1997:2) argue that Ubuntu expresses values and behaviours that are not narrowly racial or purely sectional when practised in a given society. This holds true even though, as received in our current discourse, Ubuntu is taken overtly as a uniquely African concept that is implicitly not expressed elsewhere in the world. The experience of postapartheid South Africa can be regarded as a bold experiment where the boundaries of the possibility of the integratedsociety approach are continuously tested. Now that the South-African nation has been born for the first time as an all-inclusive community, crossing traditional boundaries of race, class and ethnicity, its foundation remains fragile (Yoichi 2014:10).

It was the ideal of Mandela and Tutu to have a caring and compassionate Rainbow Nation. They opened up a way for a society that would bring a fresh meaning to the celebration of human life in all its individual uniqueness and thus demonstrate a key aspect of 'aesthetic existence' (Du Toit 2006:51). Tutu (2005) espouses an analogy of the Rainbow Nation in this manner:

At home in South Africa I have sometimes said in big meetings where you have different races together, 'Raise your hands!' Then I've said, 'Move your hands,' and, 'Look at your hands different colours representing different people. You are the rainbow people of God.' The rainbow in the Bible is the sign of peace. The rainbow is the sign of prosperity. In our world we want peace, prosperity, and justice, and we can have it when all the people of God, the rainbow people of God, work together. The endless divisions that we create between us and that we live and die for - whether they are our religions, our ethnic groups, our nationalities - are so totally irrelevant to God. God just wants us to love each other. Many, however, say that some kinds of love are better than others, condemning the love of gays and lesbians. But whether a man loves a woman or another man, or a woman loves a man or another woman, to God it is all love, and God smiles whenever we recognise our need for one another. (p. 47)

It is apparent that the manner in which Desmond Tutu tabled the term Rainbow Nation is detected from the scriptures and symbolism. God gave a sign for the covenant he made with his people and every living creature after the flood during the time of Noah. This covenant meant that there would never again be a flood to destroy people of the earth. God 
said (Gn 9:13-14): 'Whenever I bring clouds over the earth and the rainbow appears in the clouds, I will remember my covenant between me and you and all living creatures of every kind.' God made a promise to Noah that he would never send floods again, and the sign of peace would be the appearance of rainbow. Idyllically, Tutu draws the South Africans of all races, ethnicity, colour, rich and poor and different sexual orientations to a colourful symbol of a Rainbow Nation.

Tutu understands and acknowledges that South Africans are informed by different stories, stories that hold us together and stories that keep us apart. 'We inhabit the great stories of our culture. We live through stories. We are lived by the stories of our race and place' (Freedman \& Combs 1996:32). Some of the stories are the stories of apartheid that led to a huge gap between black and white people. Tutu seems to suggest a bridge of that division to each and every South African to acknowledge that South Africa is no longer a country of racism or sexism but rather a Rainbow Nation, a country of people seeking peace and prosperity together.

This is why people are led to tell and retell their stories in such a way that reinterpretation and reconstruction can eventually happen. New stories need to be constructed on the basis of which a new future can be envisioned (Muller 1999). Tutu reminds us that God has made us in such a way that we need each other. We are made for companionship and relationship. It is not good for us to be alone. Tutu (2004:25) portrays this idea in terms of the African idiom which says: 'A person is a person through other persons.' Tutu (ibid) expounds this idea as follows:

None of us comes into the world fully formed. We would not know how to think, or walk, or speak, or behave as human beings unless we learned it from other human beings. We need other human beings in order to be human. I am because other people are. The 'self-made' man or woman is really impossibility. In Africa when you ask someone 'How are you?' the reply you get is in the plural even when you are speaking to one person. A man would say, 'We are well' or 'We are not well'. He himself may be quite well, but his grandmother is not well and so he is not well either. Our humanity we know is caught up in one another's. The solitary, isolated human being is really an internal contradiction. God is smart. God does not make us too self-sufficient. We have our own gifts and that makes us unique, but I have gifts that you do not have and you have gifts that I do not have. According to Ubuntu, it is not a great good to be successful through being aggressively competitive and succeeding at the expense of others. In the end, our purpose is social and communal harmony and wellbeing. Ubuntu does not say, 'I think, therefore I am.' It says rather: 'I am human because I belong. I participate. I share'. (pp. 25-26)

Tutu's ideal for South Africa is a country that embraces multiracialism and multiculturalism. In his notion of Ubuntu, he also blends the biblical approach of creation with the nature of the commencement of Ubuntu spirituality.
It is remarkable to note that Tutu uses the amaXhosa mannerism of greeting: Unjani? It means, 'How are you?' A person replies by saying siphile ngaphandle nje kwale ka, meaning: 'We are fine except for so and so'. Tutu also makes the critical point that the concept of Ubuntu should not be used as a tool for competition against others. This reminds me of Prof. Tinyiko Sam Maluleke's ${ }^{8}$ remarks during an Ubuntu colloquium which was held at the University of Pretoria on 22-24 June 2014: 'Ubuntu should not be this nice thing that people just say anytime they want, Ubuntu should challenge the status quo.'

\section{Unity and diversity}

Reflecting on unity in diversity and diversity in unity is a vitally critical need in the post-1994 South Africa where leadership is looking for approaches to move towards building a new South Africa. Given the fact that South Africa has always been a multi-cultural society, one would have expected a rich and strong tradition of philosophical reflection on diversity. However, it is not a case, due to the past discourse of apartheid and colonial rule. We appear to be scared of diversity in ethnicities, in religious faiths and in political and ideological points of view.

Hence Msengana (2006:9) argues that South Africans do not trust each other. The heart of the problem is that race and colour seem to remain the principal axes of consciousness: people think of themselves as either black or white people. We are impatient with anything and anyone that suggests that there might just be another option worth exploring. There is nostalgia for the security in the womb of a safe sameness, and so, we shut out the stranger and the alien. We look for security in those who can provide answers that must be unassailable because no one is permitted to dissent, to question.

There is a longing for the homogenous and an allergy against the different, the other. Archbishop Njongonkulu Ndungane ${ }^{9}$ suggests that ' $[w]$ e as South Africans must create a model of racial reconciliation and cultural diversity - God urges us to create an ethic of togetherness in our diversity' (Ndungane 2006). Ndungane is pleading with South Africans to acknowledge that diversity is not a sin, but if our diversity causes us to split, it hurts God. St. Paul says the following:

All this is from God, who reconciled us to himself through Christ, and entrusts us with the ministry of reconciliation. Our unity as Christians is an accomplished fact despite our diversity, backgrounds, culture, race, and nationality, the Holy Spirit draws us together. (2 Cor 5:18)

7.AmaXhosa are the predominant group in the Eastern Cape Province of South Africa. They speak isiXhosa as language, and they are the second biggest group in South Africa. Historically, their impact has been highly recognised in political influence, tradition and religion in South Africa through people like Nelson Mandela, Oliver Tambo, Tiyo Soga and Desmond Mpilo Tutu.

8.Comments made in a discussion at the Anglican Student Federation Conference, University of Western Cape, Belville in 2006.

9.Njongonkulu Ndungane is an Emeritus Anglican bishop, a successor to Tutu. He presented his paper to the Anglican Student Federation held at University of the presented his paper to the Anglican Student Federation held at University of the
Western Cape in June 2006. He himself served a three-year sentence on Robben Island as a political prisoner from August 1963. 
Dr Allan Boesak (Dibeela, Lenka-Bula \& Vellem 2014:196) argues that the search for common ground requires '... the celebration of the diversity that God made us South Africans as Khoi, San, Xhosa, Zulu, Dutch, Sotho, Indian, Hindi, Muslim, Jewish, Christian, Black, Coloured, and White ...' A 'blacks only' mentality would crush that celebration, just as it was suffocated by a 'whites only' mentality (ibid). It is not easy to govern this wonderfully diverse and dynamic country. If we are going to talk authentically about race in the 21st century, we shall need to learn how to celebrate, to affirm and to embrace each other's differences. We need to move away from 'binary thinking'10 and focus on affirming and embracing multi-racial and multi-cultural diversity (ibid:194). The Bible says the following in Ephesians 4:3-6, 3:6:

There is one body and one Spirit - just as you were called to one hope when you were called - one Lord, one faith, one baptism; one God and Father of all, who is over all and through all and in all. This mystery is that through the gospel the Gentiles are heirs together with Israel, members together of one body, and shares together in the promises in Christ Jesus.

This quote from scripture reveals how important our peace with God and our interpersonal relationships are regardless of our race, ethnicity, class and social status. Though South Africa was once under the gross regime of apartheid which entrenched the separation of people into race and ethnic grouping, the scripture mentioned above suggests that all South Africans, black and white, have been given equal access to God and his gifts. No matter our nationality, we have become part of one body in Jesus Christ. This scripture includes our ministry of reconciliation towards one another along with unity in God's will. St. Paul stresses the unity of all people. He postulates that living in peace offers practical ways to live in unity with God and one another.

\section{Twenty years of democracy}

Democracy is viewed as a system of government that accommodates different cultures, races, religions and ethnicities and which favours tolerance. Percy Zvomuya (2009:24) suggests that ' $\ldots$ in South Africa more than 15 years into democracy, racial tensions have subsided, and yet they remain among the biggest barriers to national cohesion'. South Africa has seen a resurgence of Rainbow-Nation discourse since the nation entered the global spotlight when it hosted the FIFA World Cup in June and July 2010 (Arseneault 2010:115). During the world cup, we no longer had the poor or the rich, the black, the mixed race or the white, but all became a united rainbow people. The gathering of people from different nations in South Africa for the World Cup gave the nation the comfortable idealism of a RainbowNation moment. Steve Biko dreamt of the realisation of Ubuntu [human solidarity] according to the amaXhosa proverb: Umntu ngumntu ngabantu [A person is a person through other persons]. In time, we shall be in a position to

10.Binary thinking' towards race means that one thinks only in terms of black and white rather than appreciating the complexity of difference. The reality is that race, Whism, whitesupremacy, white privilege and the religious traditions undergirding racism, white supremacy, white privilege and the religious traditions undergirding these worldviews are far more complex than a binary equation (Dibeela et al. 2014:187). bestow upon South Africa the greatest gift possible - a more human face (Biko 1978:108).

The 2010 FIFA World Cup was one of the efficacies of that dream. It now seems that race and ethnicity have ceased to be the principal factors destabilising the daily South-African politics. This has been demonstrated in the parliamentary debates as, since the establishment of the democracy in 1994, political parties opposed to the ruling party (such as DA, IFP and $\mathrm{EFF}^{11}$ ) are represented by different races and ethnicities. People inside and outside of South Africa celebrated the democracy of the South African Rainbow Nation. Eventually, Biko's and Mandela's dream had been realised in South Africa after much sacrifice of human life and dignity in the apartheid era. However, in the 20 years of it democracy, South Africa has been boasting a reputation of being one of the most unequal countries in the world.

The unemployment rate, service-delivery protests, crime, the wide gap between the rich and the poor and the political instability jeopardise the new democracy. The rise of EFF as a political party in favour of the nationalisation of mines and natural minerals has caused unease to the ANC as ruling party. The ANC's integrity under the leadership of President Jacob Zuma has been questioned by South Africans in a manner that has never been experienced before. The National Church Leaders' Consultation (NCLC) gathered at OR Tambo International Airport on 22-23 October 2014. This convocation gathering (Makgoba 2014) made the following statement, in which they:

[c]autioned against romanticizing democracy against the very real backdrop of the vast majority of black South Africans still experiencing the pain, suffering and exclusion of being trapped in poverty and inequality. The much vaunted Rainbow Nation now has shades of grey - reflecting the social evils we are producing. (p. 1)

\section{Conclusion}

The article has shown some examples of how people understand the Rainbow Nation, an ideal of Mandela, Tutu and possibly Biko. It also puts forth a devastating image to those who still cherish illusions about the Rainbow Nation. In the introductory section, I espoused the historical origins in order to set the scene for the praxis of Ubuntu regarding our Rainbow Nation. It emerged that Ubuntu has been present in Africa as a philosophical concept that binds Africans together in a way of living a life of kindness and compassion.

In this article, Ubuntu has been hailed as a force for transformation towards democracy in South Africa, a force that inspired people of different races and classes to accept each other and to live together. Ubuntu was a central principle to recover and reconstruct the South-African society from apartheid and to reconcile the new Rainbow Nation. It is diabolical that the concepts of Ubuntu and Rainbow Nation seemed to be fading in practical terms in the 20th year of the

11.ANC: African National Congress; DA: Democratic Alliance; EFF: Economic Freedom Fighters; IFP: Inkatha Freedom Party. 
democracy. Some people perceived the Rainbow Nation as an empty term when they do not have water to drink or a place to sleep or when they do not receive the practical help that they have been promised by the government.

The abovementioned positive and negative experiences of Ubuntu and the Rainbow Nation were reflected in the interviews with my co-researchers.

Grace mentioned that, during the protest for service delivery in Olieven, the police wanted to stop the white men who were entering the place, saying it was dangerous. However, the protesters knew the white men as their fellow residents. Afterwards, the police were astonished to see white people staying in a township. Grace believes that this is part of the Rainbow Nation that Mandela and Tutu envisioned for South Africa. Mellnie again saw Ubuntu challenged when the residents of Olieven stood up together and burnt down the shop of a Nigerian drug dealer. Hence, the article mentions that Prof. Maluleke stated that Ubuntu should not only be seen as 'this nice thing' but that Ubuntu should challenge the 'status quo'.

Sadly, the spirit of Ubuntu or people centricity has been challenged by a consumer-centric notion as most South Africans seem to be driven by material possession. Corruption bears evidence to consumer-centric notions. Biko (2013) states that rampant corruption prevents many government departments from successfully executing their mandate. They are leading indicators of social decay.

Most ordinary South-African citizens are caught up between the ideological structures of the past and the ideals of the future - the 'haves' and the 'have-nots', the educated and the uneducated, the rural citizens and urban townships, the informal settlements and the suburban residential areas. The concepts of Ubuntu and Rainbow Nation therefore remain complex, and in this article, an effort was made to formulate the various dimensions of these concepts from the perspective of in-context and locally lived experiences in order to contribute practical-theologically towards insights into Ubuntu and the Rainbow Nation.

\section{Acknowledgements Competing interests}

The author declares that he has no financial or personal relationships which may have inappropriately influenced him in writing this article.

\section{References}

Arseneault, J., 2010, Races among men: Masculinity and interracial community in South African cultural text, McMaster University, Hamilton.

Bernhard, T., 2011, A historical sketch on Ubuntu, UKZN, Pietermaritzburg.

Biko, S., 1978, I write what I like, Heinemann, London.

Biko, H., 2013, The great African society: A plan for a nation gone astray, Jonathan Ball Publishers, Cape Town.

Broodryk, J., 2005, Ubuntu management philosophy, Knowres Publishing, Randburg.

Broodryk, J., 2007, Understanding South Africa: The Ubuntu way of living, Ubuntu School of Philosophy, Pretoria.

Clandinin, D.J. \& Connelly, F.M., 2000, Narrative inquiry: Experience and story in qualitative research, Jossey-Bass, San Francisco.

Dibeela, P., Lenka-Bula, P. \& Vellem, V., 2014, Prophet from the South: Essays in honour of Allan Aubrey Boesak, Sun Press, Stellenbosch.

Du Toit, W.C., 2006, The impact of knowledge systems on human development in Africa, UNISA, Pretoria.

Freedman, J. \& Combs, G., 1996, Narrative therapy: The social construction of preferred realities, W.W. Norton, New York.

Hickel, J., 2014, Al Jazeera broadcasting news commentator, Channel 406, 24 April.

Johnson, R.W., 2009, South Africa's brave new world: The beloved country since the end of apartheid, Penguin Books, London.

Jolley, D.R., 2011, '"Ubuntu": A person is a person through other persons', MA dissertation, Department of the Humanities, Southern Utah University.

Lundin, S. \& Nelson, B., 2010, An inspiring story about an African tradition of teamwork and collaboration: Ubuntu, Broadway Books, New York.

Makgoba, T., 2014, National Church Leaders Consultation: Church Leaders Statement, OR Tambo International Airport, Kempton Park.

Mathebe, L., 2002, Bound by tradition: The world of Thabo Mbeki, UNISA Press, Pretoria.

Mbigi, L., 1997, Ubuntu: The African dream in management, Knowledge Resources, Randburg.

McAllister, P., 2009, Ubuntu: Beyond belief in Southern Africa, Greening Project, Wellington. [Article Sites: New Series, vol. 6, no. 1]

Meskell, L., 2012, The nature of heritage: The new South Africa, Wiley-Blackwell, Chichester.

Msengana, N.W., 2006, 'The significance of the concept "Ubuntu" for educational management and leadership during democratic transformation in South Africa', $\mathrm{PhD}$ thesis, Department of Education, University of Stellenbosch.

Muller, J.C., 1999, Companions on the journey, Logos Electronic Publishers, Johannesburg.

Ndungane, N.W., 2006, 'Thuma Mina', Anglican Student Federation Conference, 25-30 June 2006, University of Western Cape, Belville.

Rubin, H.J. \& Rubin, I.S., 1995, Qualitative interviewing: The art of hearing data, Sage Publications, California.

Shutte, A., 2001, Ubuntu: An ethic for a New South Africa, Cluster Publications, Pietermaritzburg.

Swanson, D.M., 2007, 'Ubuntu: An African contribution to research for/with a humble togetherness', Journal of contemporary Issues in Education 2, 53-67.

Tutu, D.M., 2004, God has a dream: A vision of hope for our time, Rider, London.

Tutu, D.M., 2005, The rainbow people of God: A spiritual journey from apartheid to freedom, Doubleday, Cape Town.

Tutu, D.M., 2011, God is not a Christian: Speaking truth in times of crisis, Rider Books, London.

Van der Westhuizen, Z., 2008, 'Mentorship narratives in a local congregation: A post foundational practical theological study', PhD thesis, Faculty of Theology, University of Pretoria.

Yoichi, 2014, Multiculturalism in South Africa: The 1994 Regime Revisited, viewed 08 September 2014, from http://www.ritsumei.ac.jp

Zvomuya, P., 2009, 'Age of innocence', in Mail \& Guardian Online, viewed 23 September 2014, from http://www.mg.co.za/article/2009-10-15-the-grime-sublime 